\title{
The Physiopathological Crossroads of Aging
}

\author{
J. Lasierra-Cirujeda1 ${ }^{*}$, P. Coronel2 ${ }^{2}$ M. J. Aza Pascual-Salcedo ${ }^{3}$, M. Gimeno², \\ M. M. Aza Pascual Salcedo ${ }^{4}$, A. Lasierra-Ibañez ${ }^{5}$, C. Lasala-Aza ${ }^{6}$
}

\author{
${ }^{1}$ Logroño (La Rioja), Spain \\ ${ }^{2}$ Tedec-Meji Farma, SA, Alcala de Henares, Madrid, Spain \\ ${ }^{3}$ Pharmacy Service, La Rioja Health Department, La Rioja, Spain \\ ${ }^{4}$ Pharmacy Service, Aragon Health Service, Zaragoza, Spain \\ ${ }^{5}$ Sciences Faculty, Grade Biochemistry, University of Navarra, Navarra, Spain \\ ${ }^{6}$ Pharmacy Faculty, University of Valencia, Valencia, Spain \\ Email: ${ }^{\star}$ lasierracirujeda@gmail.com
}

How to cite this paper: Lasierra-Cirujeda, J., Coronel, P., Pascual-Salcedo, M.J.A., Gimeno, M., Pascual Salcedo, M.M.A., Lasierra-Ibañez, A. and Lasala-Aza, C. (2019) The Physiopathological Crossroads of Aging. Journal of Biosciences and Medicines, 7, 102-128.

https://doi.org/10.4236/jbm.2019.76007

Received: March 11, 2019

Accepted: June 16, 2019

Published: June 19, 2019

Copyright $\odot 2019$ by author(s) and Scientific Research Publishing Inc. This work is licensed under the Creative Commons Attribution International License (CC BY 4.0).

http://creativecommons.org/licenses/by/4.0/ Open Access

\begin{abstract}
Stress, inflammation and Plasminogen activator inhibitor 1 (PAI-1) are key mechanisms throughout the development of aging, constituting a crossroad in the most frequent pathologies that accompany it. Among metabolic processes, obesity, metabolic syndrome and type 2 diabetes mellitus are included and Alzheimer's disease among the neurodegenerative processes. Stress is a mechanism of defense of the organism against exogenous and endogenous actions called stressors. In the case of low intensity stimuli, the organism responds with actions aimed at a physiological adaptation (Homeostasis). On the other hand, when a high intensity (experimental level) or chronic stimulus (oxidative stress) is repeated, structural and functional changes are observed in different organs with activation of the hypothalamus-pituitary-adrenal axis, the renin angiotensin system and the sympathetic nervous system, stimulating the production of hormones that release cytokines with proinflammatory/antiinflammatory properties that play an important role in the previously mentioned pathologies, as well as a marked increase in PAI-1, a gene regulated by stress and by cytokines, with manifest action at the origin of thromboembolic disease, so frequent in aging. The objective of this review is to highlight the importance of the binomial stress and PAI-1 in aging and in the pathologies that accompany it. Because PAI-1 is part of the pathology and complications in aging, some authors suggest the study of PAI-1 inhibitors to achieve its physiological levels, as part of the treatment of these diseases.
\end{abstract}

\section{Keywords}

Aging. Oxidative Stress, Plasminogen Activator Inhibitor 1, Transforming Growth Factor Beta 1, Glutathione, Alzheimer's Disease 


\section{Introduction}

The concept of stress was defined decades ago by Hans Hugo Bruno Selye as a physiopathological syndrome generated by various endogenous/exogenous harmful agents. Afterward, it has been considered as the "General Adaptation Syndrome", an implicit concept of a complex process of damage and specific or nonspecific defense that accompanies us throughout our lives, especially in the aging process and in the illnesses that accompany it, whose symptoms are independent from the nature of the harmful agent as such, representing a response to the damage [1] [2] [3]. All agents can act as stressing agents (physical or psychological damage) always carrying stress and specific actions. These actions affect the organs differently and stress "per se" acts only through the general syndrome of adaptation causing defense by means of the mobilization of agonists or antagonists, in order to stabilize or adjust the response to damage. However, the general adaptation syndrome can create an organic alteration (damage) through non-specific defense [3]. In relation to adaptation to endogenous/exogenous damage, in which the brain is considered the main organ of stress reactivity [4] [5], there are different interpretations to define the cellular or organic response (allostasis/hormesis) to adapt and maintain homeostasis [6] [7] [8].

The development of the individual after its conception, development and subsequent decline, a phase that accompanies processes such as stress of lower intensity [9] [10] [11] [12], constantly produces homeostatic adaptations [13] [14], through exhibitions of sublethal stressing factors [15]. At the experimental level, tensions of greater intensity, which are associated with the administration of diphtheria toxin, produce changes in anatomical structure and function, as well as vascular infarcts by intravascular coagulation in different organs and in the hypothalamus-pituitary-adrenal (HPA) axis [4]. There is a marked increase in the expression of PAI-1 after the administration of endotoxin [16]-[21] or in the face of any inductor in acute/chronic phase, which would explain the frequency of cardiovascular-thrombotic complication in the different pathologies that accompany aging [22]. In summary, repeated episodes of chronic or acute stress generate an inflammatory process through the activation of the autonomic nervous system and the HPA axis, which causes the release of stress hormones, proinflammatory cytokines and a series of reactions in cascade, forming a pathogenic crossroad that leads to atherosclerotic, cardiovascular, metabolic and neurodegenerative injuries, leading to the presence of multiple diseases [23] [24] [25].

\section{The crossroads of physiopathology: stress, aging and PAI-1.}

The organic response to stress includes the activation of organs and systems: the HPA axis, the renin-angiotensin system and the autonomic nervous system (sympathetic/parasympathetic) [4] [26] [27] [28] [29]. After the stimuli, stress hormones, catecholamines and glucocorticoids are released, modifying the physiological functions of the endocrine, immunological and cardiovascular systems, causing metabolic, molecular alterations and proinflammatory/anti-inflammatory 
reactions (hormones, cytokines) [30]-[35] that are going to configure, in a great way, the aging and are support of the pathologies that can accompany it. Among the most frequent diseases there are: obesity, thromboembolic diseases, arteriosclerosis, hypertension, cardiovascular diseases, metabolic syndrome (MS), diabetes mellitus type 2 (DM2), neurodegenerative diseases, mainly Alzheimer's and Parkinson's diseases, and cancer. These pathologies have a common biochemical phenotype as a linkage pathogen; Stress, inflammation, decreased glutathione (GSH), oxidative stress, cytokines, transforming growth factor beta- 1 (TGF- $\beta 1$ ), interleukin 6 (IL-6), increase in the tumor necrosis factor alpha (TNF- $\alpha$ ), accompanied by a significant increase in PAI-1, induced by stress. PAI-1 is considered a star gene for its pathophysiological importance and pleiotropy, finding a large increase in this protein in senescence and aging (Figure 1) [21] [22].

A myriad of theories or hypotheses has been exposed since 1990 to explain the process of human aging [36]. From the scientific point of view, it can be considered a complex multi-causal-synergic process, inevitable and fundamental substrate for the development of different pathologies and death [37] [38]. Among the proposed theories, those that refer to free radicals [oxidative stress] [39] and genomics are the most accepted as a response to stress [40] [41] [42] [43].

The aging process involves a numerous complex of pathophysiological actions of repair and defense as a strategy, not only for its maintenance but also to avoid diseases, and is considered as a biological process outside the field of pathology [12] [44] [45] [46]. The most significant physiopathological characteristic that reveals aging is a gradual loss of function or degeneration that takes place at the molecular and cellular level, as well as at the tissue and organic level, giving rise to cellular senescence, finding chronic inflammation as a fundamental substrate [47] [48].

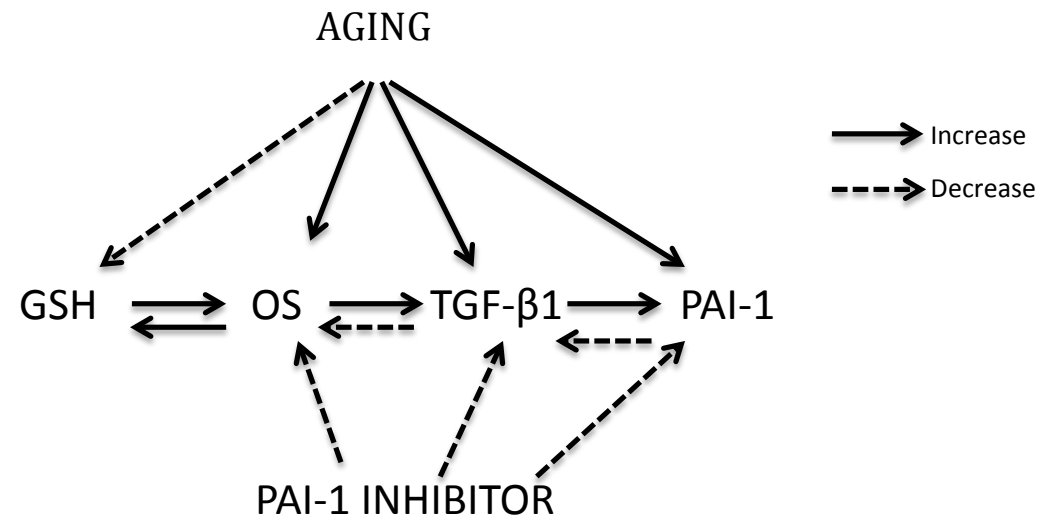

GSH: GLUTATHIONE OS: OXIDATIVE STRESS TGF- $\beta 1$ : TRANSFORMING- GROWTH FACTOR $\beta 1$ PAI-1:PLASMINOGEN ACTIVATOR INHIBITOR 1

Figure 1. Biochemical phenoype common in the aging and pathologies more frequent that accompanies. Anti PAI-1 effect. 
The gerontological effort of the research has been concentrated in achieving a healthy aging and an extension of the longevity through the hormesis induced by a mild stress with physical, biological and alimentary means [8] [10] [44] [49]-[56].

Different contributions indicate how the resistance to different acute stress stimuli is lower with age, probably due to the inability to respond to stress, as evidenced in experimental studies in rats, in which there was a marked decrease in the expression of heat shock proteins HSP, specific HSP70 [26] [27] and in those carried out in nematodes (C. elegans) subjected to different stimuli (cold, heat, oxidative stress etc.) [57].

A great variety of physiopathological changes are carried out in aging due to a harmful effect of chronic stress [29], of extrinsic or intrinsic origin, which causes an imbalance in the oxidation/oxidation defense mechanism, which leads to a decrease in reduced GSH levels, both at the tissue level and at the cellular level [58], a secondary process to the release of adrenocorticotropic hormone or cortisone, accompanied by an increase in oxidized GSH [59] [60].

GSH is the most important antioxidant agent used by each of our cells and, among other actions, regulates the functions of the immune system, protects the DNA from mutations and helps inhibit viral replication, being the most important component of the antioxidant mechanism of the brain [61] [62]. However, throughout the development of aging, GSH levels tend to decrease [58] [63]-[68] in the pathogenic entities that accompany aging [62]. This favors the action of cell damage in neurodegenerative diseases and cerebrovascular accidents [69] [70].

The progressive decrease of antioxidant GSH, which is recognized in the development of aging as a consequence of oxidative stress and the inflammatory process that accompanies it, leads to the release of different stress hormones, acute phase proteins and pro-inflammatory cytokines that are going to be part of the most frequent pathogenic entities in the development of aging. [23] [29] [30] [71].

The human being is constantly under the influence of different alarms or stimuli that generate stress. The most recognized mechanism to explain the development of aging is the "oxidative stress" caused by the decline of antioxidant defense mechanisms, which entails to the formation of harmful substances that cause damage to subcellular units, protein and nucleus acid, which can explain the most frequent pathologies in animal aging, a direct consequence of the metabolism of aerobic cells [39] [42] [72] [73] [74].

Oxidative stress has been recognized as a factor in the development of aging and a process involved in many of the pathologies associated with aging. In the field of chemistry, oxidative stress refers to the reduction of cellular potential of the cellular redox pair as the main cellular antioxidant GSH [67] [75] [76] [77] [78]. GSH constitutes a cellular defense system at different levels of stress: in the face of mild stress, an increase in GSH levels has been observed, being considered as a critical feature of preconditioning and tolerance. 
A characteristic of the brain in Alzheimer's disease is oxidative stress, as evidenced by markers of protein oxidation, lipid peroxidation, generation of oxygen free radicals by beta-amyloid peptide ( $\beta$-amyloid), the oxidation of DNA and the formation of the 3-nitrotyrosine marker among others [79] [80] [81] [82].

Stress and inflammation, as an integral process inherent to stress, are physiopathological mechanisms closely linked to aging and the most frequent pathology that sustains it [30]. Both processes form a unique path in the different chronic pathologies that develop throughout aging [83] [84] [85], leading to a significant increase, in epidemic type, of pathogenic entities associated with metabolic disorders: obesity, MS, DM2, Alzheimer's disease, Parkinson's disease, atherosclerosis and in several types of cancer (Breast, Colorectal, Liver, Pancreas). They are characterized by the presence of the binomial insulin resistance/PAI-1, the first link in the relationship between the different pathologies for the development of cardiovascular and thrombotic diseases, entities considered as the leading cause of morbidity/mortality [22] [36] [86]-[97].

\section{Cytokines and PAI-1 at the Physiopathological Crossroads}

Inflammation, as a physiological response to stress, plays a key role in the onset and progression of the different chronic pathologies that often accompany the development of physiological aging [98].

The prevalence of obesity increases in the most developed countries in all age groups, including the elderly group [99] [100] [101], correlating with stress through the activation of the HPA axis, favoring the accumulation of fat (obesity). Thus a chronic and inflammatory stress action is exerted with the release of adipose tissue from substances (cytokines, hormones), among which are of interest: adiponectin, leptin, TNF- $\alpha$, monocytic chemoattractant protein-1 (MCP-1), different interleukins (IL-1 beta, IL-6, IL-8), TGF- $\beta 1$, PAI-1, and is accompanied by oxidative stress. All this forms a crossroads (or physiopathological template) [102] [103] [104] between aging and the most frequent pathologies that support it, which are MS, DM2, neurodegenerative pathology, cancer, cardiovascular complications and thromboembolic disease [105]-[123], which increase the risk of morbidity/mortality [124]-[129].

Obesity is defined as an excessive accumulation of fatty acids in adipose tissue [130], considered as an endocrine organ [131], and as an accumulation of other cell types (immune cells, fibroblasts, endothelial cells) [132] [133] [134]. Obesity, especially of the endothelial type, is associated with inflammation and this was shown in experimental studies in rodents with obesity and diabetes, as it found an increase in the expression of TNF- $\alpha$ in adipose tissue and its ability to induce resistance to insulin [135]. Insulin resistance by glucose stimulation is a very widespread process found in patients with alteration in glucose tolerance, in patients with DM2 and up to 25 percent in non-obese patients with normal tolerance to glucose orally [136]. 
Visceral (android) obesity is the main risk factor or central and causal component of MS, also known as insulin resistance syndrome. The MS is defined as the grouping of physiopathologically interconnected processes; biochemical, clinical and metabolic factors, constituting a complex combination of central obesity (abdominal), insulin resistance/hyperinsulinemia, dyslipidemia and hypertension, chronic stress and a hypercoagulable state, due, among other factors, to the increase of the PAI-1 gene, a characteristic of the pathology that accompanies aging [135] [137] [138] [139] [140] and that increases the risk of cardiovascular complications and mortality [141].

Excessive accumulation of visceral fat is associated with high levels of adipokine and especially with high levels of PAI-1, a factor very linked to the MS and which carries with it insulin resistance [115] [142] [143] [144] [145] [146]. This suggests to the researchers, both experimentally and in clinical carried out studies, the importance of adipocytes as the main place of synthesis of PAI-1 [147] [148] [149] [150] [151], this gene may be involved in the own biology of the adipose tissue and constituting a potential risk factor in cardiovascular and metabolic pathologies, myocardial infarction, atherothrombosis, cerebrovascular accidents and thromboembolic disease, pathogenic processes that accompany aging, as well as in the rare hereditary syndromes of premature aging Huchinson-Gilford and Werne [22] [91] [142] [147] [152]-[160], which allows us to consider the PAI-1 as a therapeutic target in the field of these pathologies.

After the discovery of insulin by FG Bantin and Ch Best, 1921, the results found with the implementation of the technique of glucose tolerance in normal subjects by Himsworth [161], lead to the conclusion that there were two different entities of diabetes, one of them sensitive to insulin and the other insensitive to it. Years later, these results are interpreted as a defect of assimilation by the different tissues of the patients [162], or as a peripheral resistance of the insulin due to a defect of the postreceptor in the place of the action of the insulin [163]. It is stated that insulin resistance stimulated by insulin is found in the majority of patients with glucose intolerance, non-insulin-dependent diabetes mellitus and in approximately $25 \%$ of non-obese individuals with normal oral tolerance of glucose [136]. In the same line, patients with hypertension with or without treatment, are insulin resistant, hyperglycemic and hyperinsulinemic, and are associated with a plasma increase in the concentration of triglycerides and a decrease in high density lipoprotein cholesterol, defining this clinical-analytical conglomerate as syndrome $\mathrm{X}$ [136] being known as MS later or also defined as Insulin resistance syndrome, forming part of the beginning and evolution of processes or entities such as hypertension, DM2, atherothrombotic and atherosclerotic development, cardiovascular entities, Alzheimer's disease and cancer [118] [122] [164] [165] [166].

The oxidative stress associated with the obesity, resistance to the insulin metabolic, provides a high risk of suffering diabetes type 2, like shows for the high concentration of a isoprotane, the marker 8 -isoprostaglandin $\mathrm{F}(2$ alpha) that 
those patients present, significant of a bigger lipid peroxidation in plasma [167] [168] [169]. In this line, repeated episodes of acute or chronic stress cause an induction of answer of acute phase inside an inflammatory process as integral part of the answer to the stress, associating with the cytokines presence, mainly the IL- 6 and the reactants of sharp phase and C Reactive Protein (CRP) (30), considered as a factor of risk for the development of DM2 [170]. DM2 is associated with a sanguine increment of markers of answer of acute phase, CPR, serum amyloid A and cortisol, and the main interleukin of the inflammatory answer IL-6 [171]. Nevertheless, debate exists on the origin or the circulating markers in DM2 based on the evidence that the body fat is the main origin of the basal level and the increase of IL- 6 and CPR is a consequence of the resistance to the insulin [172].

DM2 patients have a high incidence of morbidity/mortality attributed to premature atherosclerosis or to the high incidence of cardiovascular processes, thrombosis and cerebrovascular diseases, due to their complex pathogenic arsenal associated in greater or lesser proportion with oxidative stress, obesity, hyperglycemia, dyslipidemia and hypertension, in an inflammatory setting with its courtship of proinflammatory cytokines and acute phase proteins, processes associated with the most frequent pathology in aging, and, above all, the marked increase in PAI-1, the common denominator of these pathologies and main factor of atherothrombotic complications [88] [91] [173]-[179].

\section{Metabolic Diseases and Their Affinity for Alzheimer's Disease}

Stress has a great impact on neurodegenerative diseases, having a great role in its development, progress and evolution [180]. There is evidence of the effect of stress on the brain compartment during the development of aging, mainly showing a functional decrease in cognitive activity [181]. An exposure to stress at the beginning of life or in adolescent age can program the HPA axis towards the field of pathology and increase its susceptibility in the future, to the development of metabolic, neuropsychiatric and neurodegenerative diseases [59] [182] [183] [184]. Acute/chronic stress responds to the secretion of cortisol, the most important glucocorticoid in humans due to its regulatory action on the HPA axis [185]. Glucocorticoids at the level of the brain compartment play a fundamental role in microglial proinflammatory potentiation by means of IL- $1 \beta$, IL-6, Nuclear Factor kappa B1 $\alpha$ through the N-methyl-d-aspartate receptor [186] [187]. Epidemiological studies show us that part of the pathogenic coincidences found in the complex metabolic processes that support aging (obesity, MS and DM2) accompany neurodegenerative entities, and especially Alzheimer's Disease (AD) [188]. The Rotterdam study was the first to suggest that individuals with DM2 had a higher risk of developing AD [189], and that diabetes could contribute a significant proportion in the process of $\mathrm{AD}$ in patients with cognitive disorders [190]. An increase in the prevalence of DM2 and Impaired 
Fasting Glycemia (prediabetes) has also been observed in a group of patients diagnosed with $\mathrm{AD}$ [191].

From the last decade of the last century the researchers focused their attention on the inflammatory mechanisms and their implication in the neurodegenerative processes, with special attention to the $\mathrm{AD}$, finding acute phase proteins such as alpha-1 antichymiotrypsin and CRP, as well as microglia and astroglia activated in the brain with $\mathrm{AD}$, presence of cytokines and chemokines, and activation of the classic and alternative pathways of the complement system [192] [193] [194] [195], finding high concentrations of IL-6, IL-1 $\beta$, IL-12, IL18 and high levels of TGF- $\beta$ in the cerebrospinal fluid (CSF) and in the serum before and after death [196] [197].

Scientific studies show the presence of IL- $1 \beta$ and IL- 6 in senile plaques and in cortical neurons [198], as well as their ability to stimulate the synthesis of the $\beta$-amyloid precursor protein in AD [199], linking these cytokines with the deposit of $\beta$-amyloid in $\mathrm{AD}$ [200]. Also, there are significantly elevated concentrations of these cytokines in the cerebrospinal fluid of neurodegenerative processes in $\mathrm{AD}$ and Parkinson's disease [201] intervening in the transformation of diffuse plaques [202] or pre-amyloid deposits [203], very extended in the brain, in AD neuritic plaques [204], requiring the activation of the microglia [205] [206].

The microglia is cells with phagocytic capacity that are a main part of the mechanism immune system of the central nervous system. Microglia present two functional activation pathways: classical pathway induced by Th1 cytokines (interferon gamma, IL-6, IL-12) giving expression to proinflammatory cytokines TNF , IL- $1 \beta$, IL-6, MCP-1 and to reactive oxygen species and nitric oxide and, secondly, to the alternative pathway, induced by the Th2 cytokines (IL-4, IL-13 ) giving expression to anti-inflammatory cytokines, IL-4, IL-10, TGF $\beta$ [207] [208], leading to TGF- $\beta$ contributing to the survival of phagocytic microglia after autocrine suppression of TNF- $\alpha$ production and oxidative stress [209]. Briefly, TGF- $\beta$, during the alternative activation induced by IL- 4 of microglia, acquires a very important role as antiinflammatory molecule and as immunoregulatory factor for microglia [210].

The scientific evidence recognizes the brain as an organ sensitive to insulin and responsible for the physiopathological changes of metabolic processes due to insulin receptors (IR) on the cell surface that are widely expressed in different cell groups, finding among the main ones those corresponding to the hypothalamus, hippocampus and cerebral cortex [211]-[216].

As stated, insulin resistance is a process that plays an important role in AD. There are scientific criteria to consider the binomial insulin resistance/PAI-1 as a characteristic of $\mathrm{AD}$, a pathogenic aspect that aims to support the association between metabolic diseases, the development of $\mathrm{AD}$ and related dementias [166] [217]-[225].

It is known that there are no available means for a premature diagnosis or for the application of an effective treatment for AD [226]. Since the last century 


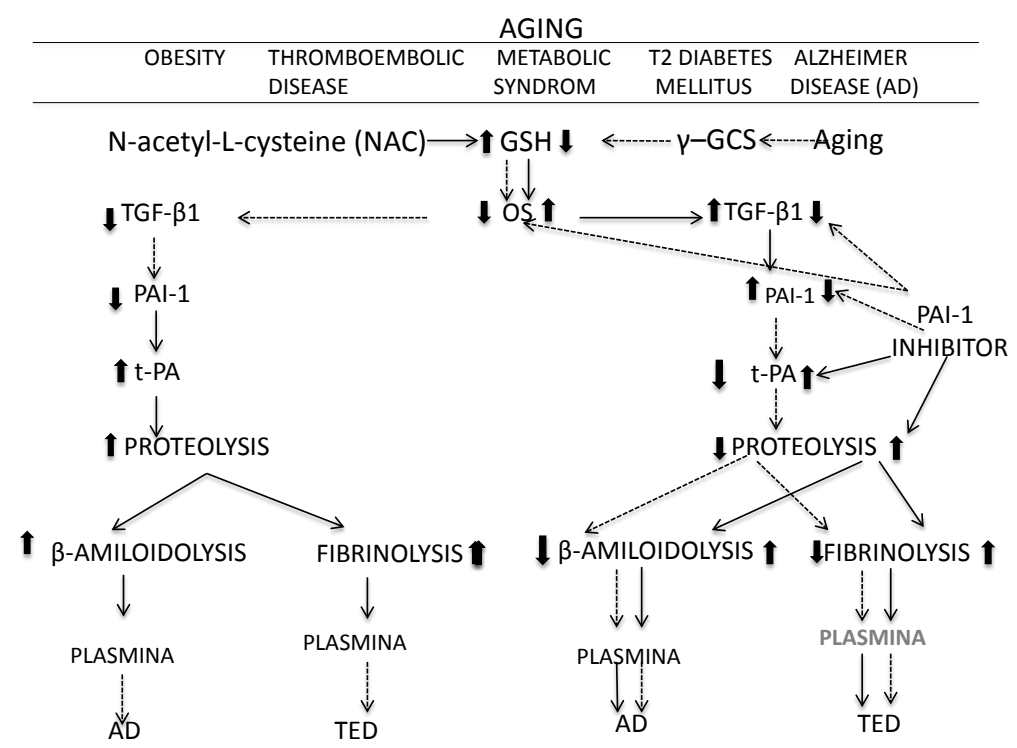

GSH: Glutathione; OS: oxidative stress; Y-GCS: Gamma Glutamylcystein synthetase; TGF- $\beta 1$ : Transforming growth factor-beta 1; PAI-1 : Plasminogen activator inhibitor-1; t-PA: Tissue Plasminogen Activator; TED: Thromboembolic disease; AD: Alzheimer's disease $\quad----\rightarrow$ Decrease

Figure 2. Proteolytic mechanism in aging and associated clinical processes. Anti-PAI-1 effect.

there has been an interest in studying biomarkers, among which the PAI-1 assessment is included. A study in neurological patients versus patients without neurological disease showed that the level of PAI-1 in CSF in neurological patients was significantly increased in the following processes: $\mathrm{AD}$, cerebral infarction, infection of the Central Nervous System (CNS], seizures due to alcohol withdrawal and CNS neoplasms, reaching the conclusion that the PAI-1 assessment could represent a non-specific marker of CNS disease [227]. Another study in patients with mild cognitive impairment or with $\mathrm{AD}$ process versus healthy controls showed that PAI-1 levels gradually increased in patients as dementia progressed, concluding that the level of plasma PAI-1 is a biomarker potential for early detection and diagnosis of $\mathrm{AD}$ [228].

Decades have been passed since the proposal of the amyloid hypothesis; hundreds of experimental and clinical trials have been carried out with little expressive results in the preventive and therapeutic field. However, the study of the PAI-1 and its main physiological inductor TGF- $\beta 1$ is taken into account [229] [230] [231], as a basis for therapeutic projects based on substances that can decrease the activity of PAI-1 at physiological levels to obtain a functionalism with stability in the field of prevention and treatment of the pathogenic entities present in the aging development [61] [232]-[245].

\section{Conclusion}

The concept of stress implicitly involves a complex process that accompanies us throughout our lives. After the stressful stimuli, the stress hormones are released, modifying the physiological functions of the endocrine, immunological 
and cardiovascular systems, causing metabolic, molecular alterations and pro-inflammatory/anti-inflammatory reactions (hormones, cytokines), which will configure in a great way aging as a support for the pathology that accompanies it, finding among the most frequent diseases: obesity, thromboembolic diseases, arthrosclerosis, hypertension, cardiovascular illnesses, MS, DM2, neurodegenerative diseases, mainly Alzheimer's and Parkinson's diseases, cancer. These pathologies have a common biochemical phenotype like nexus pathogenic of union, highlighting a significant increase in the activity of PAI-1. Highlighted PAI-1 is considered a star gene due to its path physiological importance and pleiotropy, and the basis of therapeutic projects with drugs or substances that can decrease the activity of PAI-1 at physiological levels, in order to achieve effectiveness in the field of prevention and treatment of the most frequent thromboembolic complications in the pathogenic processes that accompany the development of aging (Figure 2). For this, more scientific studies are necessarily required, whose results can serve to correct these pathologies in some way and provide greater satisfaction in this period of life.

\section{Conflicts of Interest}

The authors declare no conflicts of interest regarding the publication of this paper.

\section{References}

[1] Selye, H. (1936) Syndrome Produced by Diverse Nocuous Agents. Nature, 138, 32. https://doi.org/10.1038/138032a0

[2] Selye, H. (1946) The General Adaptation Syndrome and the Diseases of Adaptation. The Journal of Clinical Endocrinology \& Metabolism, 6, 117-230. https://doi.org/10.1210/jcem-6-2-117

[3] Selye, H. (1950)) Stress and the General Adaptation Syndrome. British Medical Journal, 1, 1383-1392. https://doi.org/10.1136/bmj.1.4667.1383

[4] Lasierra-Cirujeda, J. (1968) Contributions to the Vascular Distribution and Topography Neurosecretory in the Surface of Pituitary Contact, as Well as Concomitant Visceral Vascularization in Connection with Experimental States of Alarm. Anales de Anatomía, 17, 485-536.

[5] Tsigos, C. and Chrousos, G.P. (2002) Hypothalamic-Pituitary-Adrenal Axis, Neuroendocrine Factor and Stress. Journal of Psychosomatic Research, 53, 865-871. https://doi.org/10.1016/S0022-3999(02)00429-4

[6] Sterling, P. and Eyer, J. (1988) Allostasis: A New Paradigm to Explain Arousal Pathology. In: Fisher, S. and Reason, J., Eds., Handbook of Life Stress, Cognition and Health, John Wiley, New York, 629-649.

[7] Calabrese, E.J. (2008) Stress Biology and Hormesis: The Yerkes-Dodson Law in Psychology-A Special Case of the Hormesis Dose Response. Critical Reviews in Toxicology, 38, 453-462. https://doi.org/10.1080/10408440802004007

[8] Demirovic, C. and Rattan, S.I. (2013) Establishing Cellular Stress Response Profiles as Biomarkers of Hemodynamics, Health and Hormesis. Experimental Gerontology, 48, 94-98. https://doi.org/10.1016/j.exger.2012.02.005 
[9] Karrow, N.A. (2006) Activation of the Hypothalamic-Pituitary-Adrenal Axis and Autonomic Nervous System during Inflammation and Altered Programming of Neuroendocrine-Immune Axis during Fetal and Neonatal Development: Lessons Learned from the Model Inflammagen, Lipopolysaccharide. Brain, Behavior, and Immunity, 20, 144-158. https://doi.org/10.1016/j.bbi.2005.05.003

[10] Calabrese, E.J., Bachmann, K.A., Bailer, A.J., et al. (2007) Biological Stress Response Terminology: Integrating the Concepts of Adaptive Response and Preconditioning Stress within a Hormetic Dose-Response Framework. Toxicology and Applied Pharmacology, 122, 122-128.

[11] Rattan, S.I. (2008) Hormesis in Aging. Ageing Research Reviews, 7, 63-78. https://doi.org/10.1016/j.arr.2007.03.002

[12] Rattan, S.I. (2014) Aging Is Not a Disease: Implications for Intervention. Aging and Disease, 5, 196-202. https://doi.org/10.14336/AD.2014.0500196

[13] Bernad, C. (1957) An Introduction to the Study of Experimental Medicine. Macmillan \& Co. Ltd., London.

[14] Cannon, W.B. (1932) Physiological Regulation of Normal States: Some Tentative Postulates Concerning Biological Homeostatics. In: Pettit, A., Ed., A Charles Richet: Ses amis, ses colléges, ses eléves, Les Editions Medicales, Paris, 91-93. (In French)

[15] Davies, K.J. (2016) Adaptive Homeostasis. Molecular Aspects of Medicine, 49, 1-7. https://doi.org/10.1016/j.mam.2016.04.007

[16] Colucci, M., Páramo, J.A. and Collen, D. (1985) Generation in Plasma of a Fast-Acting Inhibitor of Plasminogen Activator in Response to Endotoxin Stimulation. Journal of Clinical Investigation, 75, 818-824. https://doi.org/10.1172/JCI111777

[17] Emeis, J.J. and Kooistra, T. (1986) Interleukin 1 and Lipopolysaccharide Induce an Inhibitor of Tissue-Type Plasminogen Activator in Vivo and in Cultured Endothelial Cells. The Journal of Experimental Medicine, 163, 1260-1266. https://doi.org/10.1084/jem.163.5.1260

[18] Pralong, G., Calandra, T., Glauser, M.P., Schellekens, J., et al. (1989) Plasminogen Activator Inhibitor 1: A New Prognostic Marker in Septic Shock. Thrombosis and Haemostasis, 61, 459-462. https://doi.org/10.1055/s-0038-1646614

[19] Quax, P.H., van den Hoogen, C.M., Verheijen, J.H., Padro, T., et al. (1990) Endotoxin Induction of Plasminogen Activator and Plasminogen Activator Inhibitor Type $1 \mathrm{mRNA}$ in Rat Tissue in Vivo. The Journal of Biological Chemistry, 265, 15560-15563.

[20] Yamamoto, K. and Loskutoff, D.J. (1996) Fibrin Deposition in Tissues from Endotoxin-Treated Mice Correlated with Decreases in the Expression of Urokinase-Type But Not Tissue-Type Plasminogen Activator. Journal of Clinical Investigation, 97, 2440-2451. https://doi.org/10.1172/JCI118691

[21] Yamamoto, K., Takeshita, K., Shimokawa, T., Yi, H., Isobe, K., et al. (2002) Plasminogen Activator Inhibitor-1 Is a Major Stress-Regulated Gene: Implications for Stress-Induced Thrombosis in Aged Individuals. Proceedings of the National Academy of Sciences of the United States of America, 99, 890-895. https://doi.org/10.1073/pnas.022608799

[22] Yamamoto, K., Takeshita, K., Kojima, T., Takamatsu, H. and Saito, H. (2005) Aging and Plasminogen Activator Inhibitor-1 (PAI-1) Regulation: Implication in the Pathogenesis of Thrombotic Disorder in the Elderly. Cardiovascular Research, 66, 276-285. https://doi.org/10.1016/j.cardiores.2004.11.013 
[23] Black, P.H. and Garbutt, L.D. (2002) Stress, Inflammation and Cardiovascular Disease. Journal of Psychosomatic Research, 52, 1-23. https://doi.org/10.1016/S0022-3999(01)00302-6

[24] Black, P.H. (2006) The Inflammatory Consequences of Psychologic Stress: Relationship to Insulin Resistance, Obesity, Atherosclerosis and Diabetes Mellitus, Type II. Medical Hypotheses, 67, 879-891. https://doi.org/10.1016/j.mehy.2006.04.008

[25] Bierhaus, A., Humpert, P.M. and Nawroth, P.P. (2006) Linking Stress to Inflammation. Anesthesiology Clinics, 24, 325-340. https://doi.org/10.1016/j.atc.2006.01.001

[26] Blake, M.J., Udelsman, R., Feulner, G.J., Norton, D.D. and Holbrook, N.J. (1991) Stress-Induced Heat Shock Protein 70 Expression in Adrenal Cortex: An Adrenocorticotropic Hormone-Sensitive, Age-Dependent Response: Proceedings of the National Academy of Sciences of the United States of America, 88, 9873-9877. https://doi.org/10.1073/pnas.88.21.9873

[27] Udelsman, R., Blake, M.J., Stagg, C.A., Li, D.-G., Putney, D.J. and Holbrook, N.J. (1993) Vascular Heat Shock Protein Expression in Response to Stress. Endocrine and Autonomic Regulation of This Age-Dependent Response. Journal of Clinical Investigation, 91, 465-473. https://doi.org/10.1172/JCI116224

[28] Chin, J.H., Okazaki, M., Hu, Z.W., Miller, J.W. and Hoffman, B.B. (1996) Activation of Heat Shock Protein (HSP) 70 and Proto-Oncogene Expression by Alpha 1 Adrenergic Agonist in Rat Aorta with Age. Journal of Clinical Investigation, 97, 2316-2323. https://doi.org/10.1172/JCI118674

[29] Black, P.H. (2002) Stress and the Inflammatory Response: A Review of Neurogenic Inflammation. Brain, Behavior, and Immunity, 16, 622-653. https://doi.org/10.1016/S0889-1591(02)00021-1

[30] Black, P.H. (2003) The Inflammatory Response Is an Integral Part of the Stress Response: Implications for Atherosclerosis, Insulin Resistance, Type II Diabetes and Metabolic Syndrome X. Brain, Behavior, and Immunity, 17, 350-364. https://doi.org/10.1016/S0889-1591(03)00048-5

[31] Kiecolt-Glaser, J.K., Preacher, K.J., MacCallun, R.C., Atkinson, C., Malarkey, W.B. and Glaser, R. (2003) Chronic Stress and Age-Related Increases in the Proinflammatory Cytokine IL-6. Proceedings of the National Academy of Sciences of the United States of America, 100, 9090-9095. https://doi.org/10.1073/pnas.1531903100

[32] Lupien, S.J., Maheu, F., Tu, M., Fiocco, A. and Schramek, T.E. (2007) The Effects of Stress and Stress Hormones on Human Cognition: Implications for the Field of Brain and Cognition. Brain and Cognition, 6, 209-237. https://doi.org/10.1016/j.bandc.2007.02.007

[33] Forsey, R.J., Thompson, J.M., Emerudh, J., Hurst, T.L., Strindhall, J., et al. (2003) Plasma Cytokine Profiles in Elderly Humans. Mechanisms of Ageing and Development, 124, 487-493. https://doi.org/10.1016/S0047-6374(03)00025-3

[34] Sapolsky, R., Armanini, M., Packan, D. and Tombaugh, G. (1987) Stress and Glucocorticoids in Aging. Endocrinology \& Metabolism Clinics of North America, 16, 965-980. https://doi.org/10.1016/S0889-8529(18)30453-5

[35] Stein-Behrens, B.A. and Sapolsky, R.M. (1992) Stress, Glucocorticoids, and Aging. Aging (Milano), 4, 197-210. https://doi.org/10.1007/BF03324092

[36] Eren, M., Boe, A.E., Murphy, S.B., Place, A.T., Nagpal, V., et al. (2014) PAI-1-Regulated Extracellular Proteolysis Governs Senescence and Survival in Klotho Mice. Proceedings of the National Academy of Sciences of the United States of America, 111, 7090-7095. https://doi.org/10.1073/pnas.1321942111 
[37] Holliday, R. (2006) Aging Is No Longer an Unsolved Problem in Biology. Annals of the New York Academy of Sciences, 1067, 1-9. https://doi.org/10.1196/annals.1354.002

[38] Liochev, S.I. (2015) Reflections on the Theories of Aging, of Oxidative Stress and of Science in General. Is It Time to Abandon the Free Radical Theory of Aging? Antioxidants \& Redox Signaling, 23, 187-207. https://doi.org/10.1089/ars.2014.5928

[39] Harman, D. (1956) Aging: A Theory Based on Free Radical and Radiation Chemistry. The Journals of Gerontology, 11, 298-300. https://doi.org/10.1093/geronj/11.3.298

[40] Knight, J.A. (2000) The Biochemistry of Aging. Advances in Clinical Chemistry, 35, 1-62. https://doi.org/10.1016/S0065-2423(01)35014-X

[41] Viña, J., Borrás, C. and Miquel, J. (2007) Theories of Ageing. Life, 59, 249-254. https://doi.org/10.1080/15216540601178067

[42] Liochev, S.I. (2013) Reactive Oxygen Species and the Free Radical Theory of Aging. Free Radical Biology \& Medicine, 60, 1-4. https://doi.org/10.1016/j.freeradbiomed.2013.02.011

[43] Moskalev, A.A., Aliper, A.M., Smit-McBride, Z., Buzdin, A. and Zhavoronkov, A. (2014) Genetics and Epigenetics of Aging and Longevity. Cell Cycle, 13, 1063-1077. https://doi.org/10.4161/cc.28433

[44] Rattan, S.I. and Clark, B.F. (2005) Understanding and Modulating Ageing. Life, 57, 297-304. https://doi.org/10.1080/15216540500092195

[45] Rattan, S.I. (2012) Biogerontology: From Here to Where? The Lord Cohen Medal Lecture-2011. Biogerontology, 13, 83-91. https://doi.org/10.1007/s10522-011-9354-3

[46] Rattan, S.I. (2013) Healthy Ageing, But What Is Health? Biogerontology, 14, 673-677. https://doi.org/10.1007/s10522-013-9442-7

[47] Campisi, J. and d'Adda di Fagagna, F. (2007) Cellular Senescence: When Bad Thing Happens to Good Cells. Nature Reviews Molecular Cell Biology, 8, 729-740. https://doi.org/10.1038/nrm2233

[48] Campisi, J. (2013) Aging, Cellular Senescence, and Cancer. Annual Review of Physiology, 75, 665-705. https://doi.org/10.1146/annurev-physiol-030212-183653

[49] Parsons, P.A. (2000) Hormesis: An Adaptive Expectation with Emphasis on Ionizing Radiation. Journal of Applied Toxicology, 20, 103-112. https://doi.org/10.1002/(SICI)1099-1263(200003/04)20:2<103::AID-JAT639>3.0.CO i2-O

[50] Calabrese, E.J. and Baldwin, L.A. (2000) Tales of Two Similar Hypotheses: The Rise and Fall of Chemical and Radiation Hormesis. Human \& Experimental Toxicology, 19, 85-97. https://doi.org/10.1191/096032700678815620

[51] Kimura, K., Tanaka, N., Nakamura, N., Takano, S. and Ohkuma, S. (2007) Knockdown of Mitochondrial Heat Shock Protein 70 Promotes Progeria-Like Phenotypes in Caenorhabditis Elegans. The Journal of Biological Chemistry, 282, 5010-5018. https://doi.org/10.1074/jbc.M609025200

[52] Mattson, M.P. (2008) Hormesis Defined. Ageing Research Reviews, 7, 1-7. https://doi.org/10.1016/j.arr.2007.08.007

[53] Gems, D. and Partridge, L. (2008) Stress-Response Hormesis and Aging: "That Which Does Not Kill Us Makes Us Stronger”. Cell Metabolism, 7, 200-203. https://doi.org/10.1016/j.cmet.2008.01.001

[54] Van Raamsdonk, J.M. and Hekimi, S. (2011) FUdR Causes a Twofold Increase in 
the Lifespan of the Mitochondrial Mutant Gas-1. Mechanisms of Ageing and Development, 132, 519-521. https://doi.org/10.1016/j.mad.2011.08.006

[55] Li, W.H., Shi, Y.C., Chang, C.H., Huang, C.W., et al. (2014) Selenite Protects Caenorhabditis elegans from Oxidative Stress via DAF-16 and TRXR-1. Molecular Nutrition \& Food Research, 58, 863-874. https://doi.org/10.1002/mnfr.201300404

[56] Bansal, A., Zhu, L.J., Yen, K. and Tissenbaum, H.A. (2015) Uncoupling Lifespan and Health Span in Caenorhabditis elegans Longevity Mutants. Proceedings of the National Academy of Sciences of the United States of America, 112, E277-E286. https://doi.org/10.1073/pnas.1412192112

[57] Dues, D.J., Andrews, E.K., Schaar, C.E., Bergsma, A.L., Senchuk, M.M. and Van Raamsdonk, J.M. (2016) Aging Causes Decreased Resistance to Multiple Stresses and a Failure to Activate Specific Stress Response Pathways. Aging (Albany NY), 8, 777-795. https://doi.org/10.18632/aging.100939

[58] Liu, H., Wang, H., Shenvi, S., Hagen, T.M. and Liu, R.M. (2004) Glutathione Metabolism during Aging and in Alzheimer Disease. Annals of the New York Academy of Sciences, 1019, 346-349. https://doi.org/10.1196/annals.1297.059

[59] Patel, R., Mcintosh, L., Mclaughlin, J., Brooke, S., Nimon, V. and Salpolsky, R. (2002) Disruptive Effects of Glucocorticoids on Glutathione Peroxidase Biochemistry in Hippocampal Cultures. Journal of Neurochemistry, 82, 118-125. https://doi.org/10.1046/j.1471-4159.2002.00948.x

[60] Miller, D.B. and O'Callaghan, J.P. (2005) Aging, Stress and the Hippocampus. Ageing Research Reviews, 4, 123-140. https://doi.org/10.1016/j.arr.2005.03.002

[61] Dringen, R. (2000) Metabolism and Functions of Glutathione in Brain. Progress in Neurobiology, 62, 649-671. https://doi.org/10.1016/S0301-0082(99)00060-X

[62] Lasierra-Cirujeda, J., Aza Pascual-Salcedo, M.J., Lasierra-Ibañez, A., Lasala-Aza, C. and Aza Pascual-Salcedo, M.M. (2016) Aging: Thromboembolic Disease, Metabolic syndrome, Type 2 Diabetes Mellitus, and Alzheimer's Disease. Journal of Biosciences and Medicine, 4, 1-20. https://doi.org/10.4236/jbm.2016.45001

[63] Stohs, S.J., Lawson, T. and Al-Turk, W.A. (1984) Changes in Glutathione and Glutathione Metabolizing Enzymes in Erythrocytes and Lymphocytes of Mice as a Function of Age. General Pharmacology, 15, 267-270. https://doi.org/10.1016/0306-3623(84)90173-3

[64] Lang, C.A., Naryshkin, S., Schneider, D.L., Mills, B.J. and Lindeman, R.D. (1992) Low Blood Glutathione Levels in Healthy Aging Adults. Journal of Laboratory and Clinical Medicine, 120, 720-725.

[65] Julius, M., Lang, C.A., Gleiberman, L., Harburg, E., DiFranceisco, W. and Schork, A. (1994) Glutathione and Morbidity in a Community-Based Sample of Elderly. Journal of Clinical Epidemiology, 47, 1021-1026. https://doi.org/10.1016/0895-4356(94)90117-1

[66] Samiec, P.S., Drews-Botsch, C., Flagg, E.W., Kurtz, J.C., Stemberg, P., Reed, R.L. and Jones, D.P. (1998) Glutathione in Human Plasma: Decline in Association with Aging, Age-Related Macular Degeneration, and Diabetes. Free Radical Biology \& Medicine, 24, 699-704. https://doi.org/10.1016/S0891-5849(97)00286-4

[67] Rebrin, I. and Sohal, R.S. (2008) Pro-Oxidant Shift in Glutathione Redox State during Aging. Advanced Drug Delivery Reviews, 60, 1545-1552.

https://doi.org/10.1016/j.addr.2008.06.001

[68] Sekhar, R.V., Patel, S.G., Guthikonda, A.P., Reid, M., Balasubramanyam, A., Taffet, G.E. and Jahoor, F. (2011) Deficient Synthesis of Glutathione Underlies Oxidative 
Stress in Aging and Can Be Corrected by Dietary Cysteine and Glycine Suppplementation. The American Journal of Clinical Nutrition, 94, 847-853. https://doi.org/10.3945/ajen.110.003483

[69] Sian, J., Dexter, D.T., Lees, A.J., Daniel, S., Jenner, P. and Marsden, C.D. (1994) Glutathione-Related Enzymes in Brain in Parkinson's Disease. Annals of Neurology, 36, 356-361. https://doi.org/10.1002/ana.410360306

[70] Schulz, J.B., Lindenau, J., Seyfried, J. and Dichgans, J. (2000) Glutathione, Oxidative Stress and Neurodegeneration. European Journal of Biochemistry, 267, 4904-4911. https://doi.org/10.1046/j.1432-1327.2000.01595.x

[71] Rahman, I. and MacNee, W. (2000) Oxidative Stress and Regulation of Glutathione in Lung Inflammation. European Respiratory Society, 16, 534-554.

https://doi.org/10.1034/j.1399-3003.2000.016003534.x

[72] Stadtman, E.R. (1992) Protein Oxidation and Aging. Science, 257, 1220-1224. https://doi.org/10.1126/science.1355616

[73] Guidi, I., Galimberti, D., Lonati, S., Novembrino, C., Bamonti, F., Tiriticco, M., et al. (2006) Oxidative Imbalance in Patients with Mild Cognitive Impairment and Alzheimer's Disease. Neurobiology of Aging, 27, 262-269. https://doi.org/10.1016/j.neurobiolaging.2005.01.001

[74] Yu, B.P. and Chung, H.Y. (2006) Adaptive Mechanism to Oxidative Stress during Aging. Mechanisms of Ageing and Development, 127, 436-443. https://doi.org/10.1016/j.mad.2006.01.023

[75] Schafer, F.Q. and Buettner, G.R. (2001) Redox Environment of the Cell as Viewed through the Redox State of Glutathione Disulfide/Glutathione Couple. Free Radical Biology \& Medicine, 30, 1191-1212. https://doi.org/10.1016/S0891-5849(01)00480-4

[76] Mytilineou, C., Kramer, B.C. and Yabut, J.A. (2002) Glutathione Depletion and Oxidative Stress. Parkinsonism \& Related Disorders, 8, 385-387. https://doi.org/10.1016/S1353-8020(02)00018-4

[77] Lasierra-Cirujeda, J., Coronel, P., Aza, M.J. and Gimeno, M. (2013) Beta-Amyloidosis and the Glutathione in Alzheimer's Disease. Journal of Blood Medicine, 4, 31-38. https://doi.org/10.2147/JBM.S35496

[78] Zhang, H., Davies, K.J.A. and Forman, H.J. (2015) Oxidative Stress Response and Nrf2 Signaling in Aging. Free Radical Biology \& Medicine, 88, 314-336. https://doi.org/10.1016/j.freeradbiomed.2015.05.036

[79] Butterfield, D.A., Yatin, S.M., Varadajaran, S. and Koppal, T. (1999) Amyloid $\beta$-Peptide-Associated Free Radical Oxidative Stress, Neurotoxicity, and Alzheimer's Disease. Methods in Enzymology, 309, 746-768. https://doi.org/10.1016/S0076-6879(99)09050-3

[80] Varadarajaran, S., Yatin, S., Aksenova and Butterfield, D.A. (2000) Review: Alzheimer's Amyloid $\beta$-Peptide-Associated Free Radical Oxidative Stress and Neurotoxicity. Journal of Structural Biology, 130, 184-208. https://doi.org/10.1006/jsbi.2000.4274

[81] Butterfield, D.A. (2002) Amyloid $\beta$-Peptide (1-42)-Induced Oxidative Stress and Neurotoxicity: Implications for Neurodegeneration in Alzheimer's Disease Brain. A Review. Free Radical Research, 36, 1307-1313. https://doi.org/10.1080/1071576021000049890

[82] Butterfield, D.A., Perluigi, M. and Sultana, R. (2006) Oxidative Stress in Alzheimer's Disease Brain: New Insights from Redox Proteomics. European Journal of Pharmacology, 545, 39-50. https://doi.org/10.1016/j.ejphar.2006.06.026 
[83] Cachofeiro, V., Goicochea, M., de Vinuesa, S.G., Oubiña, P., Lahera, V. and Luño, J. (2008) Oxidative Stress and Inflammation, a Link between Chronic Kidney Disease and Cardiovascular Disease. Kidney International Supplements, 111, S4-S9. https://doi.org/10.1038/ki.2008.516

[84] Tucker, P.S., Scanlan, A.T. and Dalbo, V.J. (2015) Chronic Kidney Disease Influences Multiple Systems: Describing the Relationship between Stress, Inflammation, Kidney Damage, and Concomitant Disease. Oxidative Medicine and Cellular Longevity, 2015, Article ID: 806358. https://doi.org/10.1155/2015/806358

[85] Kumar-Biswas, S. (2016) Does the Interdependence between Oxidative Stress and Inflammation Explain the Antioxidant Paradox? Oxidative Medicine and Cellular Longevity, 2016, Article ID: 5698931. https://doi.org/10.1155/2016/5698931

[86] Kohler, H.-P. (2002) Insulin Resistance Syndrome: Interaction with Coagulation and Fibrinolysis. Swiss Medical Weekly, 132, 241-252.

[87] Hubert, H.B., Feinleib, M., McNamara, P.M. and Castelli, W.P. (1983) Obesity as an Independent Risk Factor for Cardiovascular Disease: A 26-Year Follow-Up of Participants in the Framingham Heart Study. Circulation, 67, 968-977. https://doi.org/10.1161/01.CIR.67.5.968

[88] Juhan-Vague, I. and Alessi, M.C. (1997) PAI-1, Obesity, Insulin Resistance and Risk of Cardiovascular Events. Thrombosis and Haemostasis, 78, 656-660. https://doi.org/10.1055/s-0038-1657607

[89] Mokdad, A.H., Serdula, M.K., Dietz, W.H., Bowman, B.A., Marks, J.S. and Koplan, J.P. (1999) The Spread of the Obesity Epidemic in United States, 1991-1998. JAMA, 282, 1519-1522. https://doi.org/10.1001/jama.282.16.1519

[90] Ceriello, A. and Motz, E. (2004) Is Oxidative Stress the Pathogenic Mechanism Underlying Insulin Resistance, Diabetes, and Cardiovascular Disease? The Common Soil Hypothesis Revisited. Arteriosclerosis, Thrombosis, and Vascular Biology, 24, 816-823. https://doi.org/10.1161/01.ATV.0000122852.22604.78

[91] Grant, P.J. (2007) Diabetes Mellitus as a Prothrombotic Condition. Journal of Internal Medicine, 262, 157-172. https://doi.org/10.1111/j.1365-2796.2007.01824.x

[92] Kyrou, I. and Tsigos, C. (2007) Stress Mechanisms and Metabolic Complications. Hormone and Metabolic Research, 39, 430-438. https://doi.org/10.1055/s-2007-981462

[93] Alessi, M.C. and Juhan-Vague, I. (2008) Metabolic Syndrome, Haemostasis and Thrombosis. Thrombosis and Haemostasis, 99, 995-1000. https://doi.org/10.1160/TH07-11-0682

[94] Grundy, S.M. (2008) Metabolic Syndrome Pandemic. Arteriosclerosis, Thrombosis, and Vascular Biology, 28, 629-636. https://doi.org/10.1161/ATVBAHA.107.151092

[95] Tsugane, S. and Inoue, M. (2010) Insulin Resistance and Cancer: Epidemiological Evidence. Cancer Science, 101, 1073-1079. https://doi.org/10.1111/j.1349-7006.2010.01521.x

[96] Rohleder, N. (2014) Stimulation of Systemic Low-Grade Inflammation by Psychosocial Stress. Psychosomatic Medicine, 76, 181-189. https://doi.org/10.1097/PSY.0000000000000049

[97] Athauda, D. and Foltynie, T. (2016) Insulin Resistance and Parkinson's Disease: A New Target for Disease Modification? Progress in Neurobiology, 145-146, 98-120. https://doi.org/10.1016/j.pneurobio.2016.10.001

[98] Lavretsky, H. and Newhouse, P.A. (2012) Stress, Inflammation and Aging. The American Journal of Geriatric Psychiatry, 20, 729-733. 
https://doi.org/10.1097/JGP.0b013e31826573cf

[99] Arterbum, D.E., Crane, P.K. and Sullivan, S.D. (2004) The Coming Epidemic of Obesity in Elderly Americans. Journal of the American Geriatrics Society, 52, 1907-1912. https://doi.org/10.1111/j.1532-5415.2004.52517.x

[100] Mathus-Vliegen, E.M. (2012) Obesity and the Elderly. Journal of Clinical Gastroenterology, 46, 533-544. https://doi.org/10.1097/MCG.0b013e31825692ce

[101] Gallus, S., Lugo, A., Murisic, B., Bosetti, C., Boffetta, P. and La Vecchia, C. (2015) Overweight and Obesity in 16 European Countries. European Journal of Nutrition, 54, 679-689. https://doi.org/10.1007/s00394-014-0746-4

[102] Coppack, S.W. (2001) Pro-Inflammatory Cytokines and Adipose Tissue. Proceedings of the Nutrition Society, 60, 349-356. https://doi.org/10.1079/PNS2001110

[103] Kyrou, I., Chrousos, G.P. and Tsigos, C. (2006) Stress, Visceral Obesity, and Metabolic Complications. Annals of the New York Academy of Sciences, 1083, 77-110. https://doi.org/10.1196/annals.1367.008

[104] Kyrou, I. and Tsigos, C. (2009) Stress Hormones: Physiological Stress and Regulation of Metabolism. Current Opinion in Pharmacology, 9, 787-793. https://doi.org/10.1016/j.coph.2009.08.007

[105] Zhang, Y., Proenca, R., Maffei, M., Barone, M., Leopold, L. and Friedman, J.M. (1994) Positional Cloning of the Mouse Obese Gene and Its Human Homologue. Nature, 372, 425-432. https://doi.org/10.1038/372425a0

[106] Mohamed-Ali, V., Pinkney, J.H. and Coppack, S.W. (1998) Adipose Tissue as an Endocrine and Paracrine Organ. International Journal of Obesity and Related Metabolic Disorders, 22, 1145-1158. https://doi.org/10.1038/sj.ijo.0800770

[107] Gabay, C. and Kushner, I. (1999) Acute-Phase Proteins and Other Systemic Responses to Inflammation. The New England Journal of Medicine, 340, 448-454. https://doi.org/10.1056/NEJM199902113400607

[108] Mertens, I. and Van Gaal, L.F. (2002) Obesity, Haemostasis, and the Fibrinolytic System. Obesity Reviews, 3, 85-101. https://doi.org/10.1046/j.1467-789X.2002.00056.x

[109] Prins, J.B. (2002) Adipose Tissue as an Endocrine Organ. Best Practice \& Research: Clinical Endocrinology \& Metabolism, 16, 639-651. https://doi.org/10.1053/beem.2002.0222

[110] Renehan, A.G., Tyson, M., Egger, M., Heller, R.F. and Zwahlen, M. (2008) Body-Mass Index and Incidence of Cancer: A Systematic Review and Meta-Analysis of Prospective Observational Studies. The Lancet, 371, 569-578. https://doi.org/10.1016/S0140-6736(08)60269-X

[111] Parr, C.L., Batty, G.D., Lam, T.H., Barzi, F., Fang, X., Ho, S.C., et al. (2010) Body-Mass Index and Cancer Mortality in the Asia-Pacific Cohort Studies Collaboration: Pooled Analyses of 424,519 Participants. The Lancet Oncology, 11, 741-752. https://doi.org/10.1016/S1470-2045(10)70141-8

[112] Galic, S., Oakhill, J.S. and Steinberg, G.R. (2010) Adipose Tissue as an Endocrine Organ. Molecular and Cellular Endocrinology, 316, 129-139. https://doi.org/10.1016/j.mce.2009.08.018

[113] Yang, W.-S., Lee, W.-J., Funahashi, T., Tanaka, S., Matsuzawa, Y., Chao, C.L., Chen, C.L., Tai, T.Y. and Chuang, L.M. (2001) Weight Reduction Increases Plasma Levels of and Adipose-Derived Anti-Inflammatory Protein, Adiponectin. The Journal of Clinical Endocrinology \& Metabolism, 86, 3815-3819.

https://doi.org/10.1210/jcem.86.8.7741 
[114] Doyle, S.L., Donohoe, C.L. and Reynolds, J.V. (2012) Visceral Obesity, Metabolic Syndrome, Insulin Resistance and Cancer. Proceedings of the Nutrition Society, 71, 181-189. https://doi.org/10.1017/S002966511100320X

[115] Uchida, Y., Takeshita, K., Yamamoto, K., Kikuchi, R., Nakayama, T., Nomura, M., et al. (2012) Stress Augments Insulin Resistance and Prothrombotic State: Role of Visceral Adipose-Derived Monocyte Chemoattractant Protein-1. Diabetes, 61, 1552-1561. https://doi.org/10.2337/db11-0828

[116] Brinkley, T.E., Hsu, F.C., Beavers, K.M., Church, T.S., Goodpaster, B.H., Stafford, R.S., Pahor, M., Krichevsky, S.B. and Nicklas, B.J. (2012) Total and Abdominal Adiposity Are Associated with Inflammation in Older Adults Using a Factor Analysis Approach. The Journals of Gerontology. Series A, Biological Sciences and Medical Sciences, 67, 1099-1106. https://doi.org/10.1093/gerona/gls077

[117] Furukawa, S., Fujita, T., Shimabukuro, M., Iwaki, M., Yamada, Y., Nakajima, Y., Nakayama, O., et al. (2004) Increased Oxidative Stress in Obesity and Its Impact on Metabolic Syndrome. Journal of Clinical Investigation, 114, 1752-1761. https://doi.org/10.1172/JCI21625

[118] Cowey, S. and Hardey, R.W. (2006) The Metabolic Syndrome: A High-Risk State for Cancer? The American Journal of Pathology, 169, 1505-1522. https://doi.org/10.2353/ajpath.2006.051090

[119] Wellen, K.E. and Hotamisligil, G.S. (2005) Inflammation, Stress, and Diabetes. Journal of Clinical Investigation, 115, 1111-1119. https://doi.org/10.1172/JCI25102

[120] Karastergiou, K. and Mohamed-Ali, V. (2010) The Autocrine and Paracrine Roles of Adipokines. Molecular and Cellular Endocrinology, 318, 69-78. https://doi.org/10.1016/j.mce.2009.11.011

[121] Giovannucci, E., Harlan, D.M., Archer, M.C., Bergenstal, R.M., Gapstur, S.M., Habel, L.A., Pollak, M., et al. (2010) Diabetes and Cancer: A Consensus Report. Diabetes Care, 33, 1674-1685. https://doi.org/10.2337/dc10-0666

[122] Arcidiacono, B., Liritano, S., Nocera, A., et al. (2012) Insulin Resistance and Cancer Risk: An Overview of the Pathogenetic Mechanisms. Experimental Diabetes Research, 2012, Article ID: 789174. https://doi.org/10.1155/2012/789174

[123] Marseglia, L., Manti, S., D’Angelo, G., Nicotera, A., Parisi, E., Di Rosa, G. and Arrigo, T. (2014) Oxidative Stress in Obesity: A Critical Component in Human Diseases. International Journal of Molecular Sciences, 16, 378-400. https://doi.org/10.3390/ijms16010378

[124] Michaud, M., Balardy, L., Moulis, G., Gaudin, C., Peyrot, C., Vellas, B., Cesari, M. and Nourhashemi, F. (2013) Proinflammatory Cytokines, Aging, and Age-Related Diseases. Journal of the American Medical Directors Association, 14, 877-882. https://doi.org/10.1016/j.jamda.2013.05.009

[125] Pedersen, B.K., Bruunsgaard, H., et al. (2000) Cytokines in Aging and Exercise. International Journal of Sports Medicine, 1, S4-S9. https://doi.org/10.1055/s-2000-1444

[126] Bruunsgaard, H., Pedersen, M. and Pedersen, B.K. (2001) Aging and Proinflammatory Cytokines. Current Opinion in Hematology, 8, 131-136. https://doi.org/10.1097/00062752-200105000-00001

[127] Brüünsgaard, H. and Pedersen, B.K. (2003) Age-Related Inflammatory Cytokines and Disease. Immunology and Allergy Clinics of North America, 23, 15-39. https://doi.org/10.1016/S0889-8561(02)00056-5

[128] Krabbe, K.S., Pedersen, M. and Brüünsgaard, H. (2004) Inflammatory Mediators in 
the Elderly. Experimental Gerontology, 39, 687-699.

https://doi.org/10.1016/j.exger.2004.01.009

[129] Alvarez-Rodríguez, L., López-Hoyos, M., Muñoz-Cacho, P. and Martínez Taboada, V.M. (2012) Aging Is Associated with Circulating Cytokine Dysregulation. Cellular Immunology, 273, 124-132. https://doi.org/10.1016/j.cellimm.2012.01.001

[130] Sikaris, K.A. (2004) The Clinical Biochemistry of Obesity. The Clinical Biochemist Reviews, 25, 165-181.

[131] Kershaw, E.E. and Flier, J.S. (2004) Adipose Tissue as an Endocrine Organ. The Journal of Clinical Endocrinology \& Metabolism, 89, 2548-2556. https://doi.org/10.1210/jc.2004-0395

[132] Frayn, K.N., Karpe, F., Fielding, B.A., Macdonald, I.A. and Coppack, S.W. (2003) Integrative Physiology of Human Adipose Tissue. International Journal of Obesity and Related Metabolic Disorders, 27, 875-888. https://doi.org/10.1038/sj.ijo.0802326

[133] Fain, J.N., Madan, A.K., Hiler, M.L., Cheema, P. and Bahouth, S.W. (2004) Comparison of the Release of Adipokines by Adipose Tissue, Adipose Tissue Matrix, and Adipocytes from Visceral and Subcutaneous Abdominal Adipose Tissues of Obese Humans. Endocrinology, 145, 2273-2282. https://doi.org/10.1210/en.2003-1336

[134] Cristancho, A.G. and Lazar, M.A. (2011) Forming Functional Fat: A Growing Understanding of Adipocyte Differentiation. Nature Reviews Molecular Cell Biology, 12, 722-734. https://doi.org/10.1038/nrm3198

[135] Hostamisliging, G.S., Shargill, N.S. and Spiegelman, B.N. (1993) Adipose Expression of Tumor Necrosis Factor-Alpha: Direct Role in Obesity-Linked Insulin Resistance. Science, 259, 87-91. https://doi.org/10.1126/science.7678183

[136] Reaven, G.M. (1988) Banting Lecture 1988. Role of Insulin Resistance in Human Disease. Diabetes, 37, 1595-1607. https://doi.org/10.2337/diabetes.37.12.1595

[137] Kahn, B.B. and Flier, J.S. (2000) Obesity and Insulin Resistance. Journal of Clinical Investigation, 106, 473-481. https://doi.org/10.1172/JCI10842

[138] Kaur, J. (2014) A Comprehensive Review on Metabolic Syndrome. Cardiology Research and Practice, 2014, Article ID: 943162. https://doi.org/10.1155/2014/943162

[139] Reaven, G.M., Lithell, H. and Landsberg, L. (1996) Hypertension and Associated Metabolic Abnormalities: The Role of Insulin Resistance and the Sympathoadrenal System. The New England Journal of Medicine, 334, 374-381. https://doi.org/10.1056/NEJM199602083340607

[140] Goossens, G.H. (2008) The Role of Adipose Tissue Dysfunction in the Pathogenesis of Obesity-Related Insulin Resistance. Physiology \& Behavior, 94, 206-218. https://doi.org/10.1016/j.physbeh.2007.10.010

[141] Juhan-Vague, I., Alessi, M.C. and Vague, P. (1991) Increased Plasma Plasminogen Activator Inhibitor 1 Levels. A Possible Link between Insulin Resistance and Atherothrombosis. Diabetologia, 34, 457-462. https://doi.org/10.1007/BF00403280

[142] Mertens, I., Verrijken, A., Michiels, J.J., Van der Planken, M., Ruige, J.B. and Van Gaal, L.F. (2006) Among Inflammation and Coagulation Markers, PAI-1 Is a True Component of the Metabolic Syndrome. International Journal of Obesity, 30, 1308-1314. https://doi.org/10.1038/sj.ijo.0803189

[143] Bastard, J.P., Maachi, M., Lagathu, C., et al. (2006) Recent Advances in the Relationship between Obesity, Inflammation, and Insulin Resistance. European Cytokine Network, 17, 4-12.

[144] Kim, C.S., Park, H.S., Kawada, T., Kim, J.H., Lim, D., Hubbard, N.E., et al. (2006) 
Circulating Levels of MCP-1 and IL-8 Are Elevated in Human Obese Subjects and Associated with Obesity-Related Parameters. International Journal of Obesity, 30, 1347-1355. https://doi.org/10.1038/sj.ijo.0803259

[145] Rabe, K., Lehrke, M., Parhofer, K.G. and Broedl, U.C. (2008) Adipokines and Insulin Resistance. Molecular Medicine, 14, 741-751. https://doi.org/10.2119/2008-00058.Rabe

[146] Antuna-Puente, B., Feve, B., Fellahi, S. and Bastard, J.P. (2008) Adypokines: The Missing Link between Insulin Resistance and Obesity. Diabetes \& Metabolism, 34, 2-11. https://doi.org/10.1016/j.diabet.2007.09.004

[147] Loskutoff, D.J. and Samad, F. (1998) The Adipocyte and Hemostatic Balance in Obesity: Studies of PAI. Arteriosclerosis, Thrombosis, and Vascular Biology, 18, 1-6. https://doi.org/10.1161/01.ATV.18.1.1

[148] Bastard, J.P. and Piéroni, J. (1999) Plasma Plasminogen Activator Inhibitor 1, Insulin Resistance and Android Obesity. Biomedicine \& Pharmacotherapy, 53, 455-461. https://doi.org/10.1016/S0753-3322(00)88103-2

[149] Matsuzawa, Y., Funahashi, T. and Nakamura (1999) Molecular Mechanism of Metabolic Syndrome X: Contribution of Adipocytokines Adipocyte-Derived Bioactive Substances. Annals of the New York Academy of Sciences, 892, 146-154. https://doi.org/10.1111/j.1749-6632.1999.tb07793.x

[150] Skurk, T. and Hauner, H. (2004) Obesity and Impaired Fibrinolysis: Role of Adipose Production of Plasminogen Activator Inhibitor-1. International Journal of Obesity and Related Metabolic Disorders, 28, 1357-1364. https://doi.org/10.1038/sj.ijo.0802778

[151] You, A., Nicklas, B.J., Ding, J., Pennix, B.W., Goodpaster, B.H., Bauer, D.C., et al. (2008) The Metabolic Syndrome Is Associated with Circulating Adipokines in Older Adults across a Wide Range of Adiposity. The Journals of Gerontology. Series A, Biological Sciences and Medical Sciences, 63, 414-419. https://doi.org/10.1093/gerona/63.4.414

[152] Shimomura, I., Funahashi, T., Takahashi, M., Maeda, K., Kotani, K., Nakamura, T., et al. (1996) Enhanced Expression of PAI-1 in Visceral Fat: Possible Contributor to Vascular Disease in Obesity. Nature Medicine, 2, 800-803. https://doi.org/10.1038/nm0796-800

[153] Jugan-Vague, I., Morange, P.E. and Alessi, M.C. (2002) The Insulin Resistance Syndrome: Implications for Thrombosis and Cardiovascular Disease. Pathophysiology of Haemostasis and Thrombosis, 32, 269-273. https://doi.org/10.1159/000073579

[154] Ford, E.S. (2004) The Metabolic Syndrome and Mortality from Cardiovascular Disease and All-Causes: Finding from the National Health and Nutrition Examination Survey II Mortality Study. Atherosclerosis, 173, 309-314.

https://doi.org/10.1016/S0021-9150(04)00015-2

[155] Alberti, K.G., Zimmet, P. and Shaw, J. (2005) The Metabolic Syndrome-A New Worldwide Definition. The Lancet, 366, 1059-1062.

https://doi.org/10.1016/S0140-6736(05)67402-8

[156] Morange, P.E., Saut, N., Alessi, M.C., Yudkin, J.S., Margaglione, M., Di Minno, G., et al. (2007) Association of Plasminogen Activator Inhibitor (PAI-1) (SERPINE 1) SNPs with Myocardial Infarction, Plasma PAI-1, and Metabolic Parameters: The HIFMECH Study. Arteriosclerosis, Thrombosis, and Vascular Biology, 27, 2250-2257. https://doi.org/10.1161/ATVBAHA.107.149468

[157] Odrowaz-Sypniewska, G. (2007) Markers of Pro-Inflammatory and Pro-Thrombotic State in the Diagnosis of Metabolic Syndrome. Advances in Medical Sciences, 52, 
246-250

[158] Alessi, M.C., Poggi, M. and Jugan-Vague, I. (2007) Plasminogen Activator Inhibitor-1, Adipose Tissue and Insulin Resistance. Current Opinion in Lipidology, 18, 240-245. https://doi.org/10.1097/MOL.0b013e32814e6d29

[159] Alberti, K.G., Eckel, R.H., Grundy, S.M., Zimmet, P.Z., Cleeman, J.I., Donato, K.A., et al. (2009) Harmonizing the Metabolic Syndrome: A Joint Interim Statement of the International Diabetes Federation Task Force on Epidemiology and Prevention; National Heart, Lung, and Blood Institute; American Heart Association; World Heart Federation; International Atherosclerosis Society; and International Association for the Study of Obesity. Circulation, 120, 1640-1645. https://doi.org/10.14341/2071-8713-5281

[160] Dentali, F., Squizzato, A. and Ageno, W. (2009) The Metabolic Syndrome as a Risk Factor for Venous and Arterial Thrombosis. Seminars in Thrombosis and Hemostasis, 35, 451-457. https://doi.org/10.1055/s-0029-1234140

[161] Himsworth, H.P. (1936) Management of Diabetes Mellitus. British Medical Journal, 2, 188-190. https://doi.org/10.1136/bmj.2.3942.188

[162] Shen, S.W., Reaven, G.M. and Farquhar, J.W. (1970) Comparison of Impedance to Insulin-Mediated Glucose Uptake in Normal Subjects and in Subjects with Latent Diabetes. Journal of Clinical Investigation, 49, 2151-2160. https://doi.org/10.1172/JCI106433

[163] Fink, R.I., Kolterman, O.G., Griffin, J. and Olefsky, J.M. (1983) Mechanisms of Insulin Resistance in Aging. Journal of Clinical Investigation, 71, 1523-1535. https://doi.org/10.1172/JCI110908

[164] Weiderpass, E., Gridley, G., Nyren, O., Ekbom, A., Persson, I. and Adami, H.O. (1997) Diabetes Mellitus and Risk of Large Bowel Cancer. Journal of the National Cancer Institute, 89, 660-661. https://doi.org/10.1093/jnci/89.9.660

[165] Jee, S.H., Ohrr, H., Sull, J.W., Yun, J.E., Ji, M. and Samet, J.M. (2005) Fasting Serum Glucose Level and Cancer Risk in Korean Men and Women. JAMA, 293, 194-202. https://doi.org/10.1001/jama.293.2.194

[166] Neth, B.J. and Craft, S. (2017) Insulin Resistance and Alzheimer's Disease: Bionergetic Linkages. Frontiers in Aging Neuroscience, 9, 345. https://doi.org/10.3389/fnagi.2017.00345

[167] Meigs, J.B., Larson, M.G., Fox, C.S., Keaney, J.F., Vasan, R.S. and Benjamin, E.J. (2007) Association of Oxidative Stress, Insulin Resistance, and Diabetes Risk Phenotypes: The Framingham Offspring Study. Diabetes Care, 30, 2529-2535. https://doi.org/10.2337/dc07-0817

[168] Gopaul, N.K., Anggärd, E.E., Maller, A.I., Betteridge, D.J., Wolff, S.P. and Nourooz-Zadeh, J. (1995) Plasma 8-epi-PGF2 Alpha Levels Are Elevated in Individuals with Non-Insulin Dependent Diabetes Mellitus. FEBS Letters, 368, 225-229. https://doi.org/10.1016/0014-5793(95)00649-T

[169] Abbasian, M., Delvarianzadeh, M., Ebrahim, H., Khosravi, F. and Nourozi, P. (2018) Relationship between Serum Levels of Oxidative Stress and Metabolic Syndrome Components. Diabetes \& Metabolic Syndrome, 12, 497-500. https://doi.org/10.1016/j.dsx.2018.03.015

[170] Schmidt, M.I., Duncan, B.B., Sharrett, A.R., Lindberg, G., Savage, P.J., Offenbacher, S., Azambuja, M.I., Tracy, R.P. and Heiss, G. (1999) Markers of Inflammation and Prediction of Diabetes Mellitus in Adults (Atherosclerosis Risk in Communities Study, a Cohort Study). The Lancet, 353, 52.

https://doi.org/10.1016/S0140-6736(99)01046-6 
[171] Pickup, J.C. and Crook, M.A. (1998) Is Type II Diabetes Mellitus a Disease of the Innate Immune System? Diabetologia, 41, 1241-1248. https://doi.org/10.1007/s001250051058

[172] Greenfild, J.R. and Campbell, L.V. (2006) Relationship between Inflammation, Insulin Resistance and Type 2 Diabetes: Cause or Effect? Current Diabetes Reviews, 2 , 195-211. https://doi.org/10.2174/157339906776818532

[173] Pan, W.H., Cedres, L.B., Liu, K., Dyer, A., Schoenberger, J.A., Shelkelle, R.B., Stamier, R., et al. (1986) Relationship of Clinical Diabetes and Asymptomatic Hyperglycemia to Risk of Coronary-Heart Disease Mortality in Men and Women. American Journal of Epidemiology, 123, 504-516. https://doi.org/10.1093/oxfordjournals.aje.a114266

[174] Auwerx, J., Bouillon, R., Collen, D. and Geboers, J. (1988) Tissue-Type Plasminogen Activator Antigen and Plasminogen Activator Inhibitor in Diabetes Mellitus. Arteriosclerosis, 8, 68-72. https://doi.org/10.1161/01.ATV.8.1.68

[175] Uusitupa, M.I., Niskanen, L.K., Siitonen, O., Voutilainen, E. and Pyorala, K. (1990) 5-Year Incidence of Atherosclerotic Vascular Disease in Relation to General Risk Factors, Insulin Level, and Abnormalities in Lipoprotein Composition in Non-Insulin-Dependent Diabetic and Nondiabetic Subjects. Circulation, 82, 27-36. https://doi.org/10.1161/01.CIR.82.1.27

[176] Schneider, D.J., Nordt, T.K. and Sobel, B.E. (1993) Attenuated Fibrinolysis and Accelerated Atherogenesis in Type II Diabetic Patients. Diabetes, 42, 1-7. https://doi.org/10.2337/diabetes.42.1.1

[177] Urano, T., Kojima, Y., Takahashi, M., Serizawa, K., Sakakibara, K., Takada, Y. and Takada, A. (1993) Impaired Fibrinolysis in Hypertension and Obesity Due to High Plasminogen Activator Inhibitor-1 Level in Plasma. The Japanese Journal of Physiology, 43, 221-228. https://doi.org/10.2170/jiphysiol.43.221

[178] Fujii, S., Goto, D., Zaman, T., Ishimori, N., Watano, K., Kaneko, T., Okada, H., Makiguchi, M., Nakawana, T. and Kitabatake, A. (1998) Diminished Fibrinolysis and Thrombosis: Clinical Implications for Accelerated Atherosclerosis. Journal of Atherosclerosis and Thrombosis, 5, 76-81. https://doi.org/10.5551/jat1994.5.76

[179] Lyon, C.J. and Hsueh, W.A. (2003) Effect of Plasminogen Activator Inhibitor-1 in Diabetes Mellitus and Cardiovascular Disease. The American Journal of Medicine, 8, 62S-68S. https://doi.org/10.1016/j.amjmed.2003.08.014

[180] Jung, R.G., Motazedian, P., Ramirez, F.D., Di Santo, P., Visintini, S., Faraz, M.A., Labinaz, A., Jung, Y., et al. (2018) Association between Plasminogen Activator Inhibitor-1 and Cardiovascular Events: A Systematic Review and Meta-Analysis. Thrombosis Journal, 16, 12. https://doi.org/10.1186/s12959-018-0166-4

[181] Esch, T., Stefano, G.B., Fricchione, G.L. and Benson, H. (2002) The Role of Stress in Neurodegenerative Diseases and Mental Disorders. Neuro Enocrinology Letters, 23, 199-208.

[182] Everson-Rose, S.A., Mendes de Leon, C.F., Bienias, J.L., Wilson, R.S. and Evans, D.A. (2003) Early Life Conditions and Cognitive Functioning in Later Life. American Journal of Epidemiology, 158, 1083-1089. https://doi.org/10.1093/aje/kwg263

[183] Brunson, K.L., Kramar, E., Lin, B., Chen, Y., Colgin, L.L., Yanagihara, T.K., Lynch, G. and Baram, T.Z. (2005) Mechanism of Late-Onset Cognitive Decline after Early-Life Stress. Journal of Neuroscience, 25, 9328-9338. https://doi.org/10.1523/JNEUROSCI.2281-05.2005

[184] Chen, Y. and Baram, T.Z. (2016) Toward Understanding How Early-Life Stress Reprograms Cognitive and Emotional Brain Networks. Neuropsychopharmacology, 
41, 197-206. https://doi.org/10.1038/npp.2015.181

[185] Vyas, S., Rodrigues, A.J., Silva, J.M., Tronche, F., Almeida, O.F., Sousa, N. and Sotiropoulos, I. (2016) Chronic Stress and Glucocorticoids: From Neuronal Plasticity to Neurodegeneration. Neural Plasticity, 2016, Article ID: 6391686. https://doi.org/10.1155/2016/6391686

[186] Swaab, D.F., Bao, A.M. and Lucassen, P.J. (2005) The Stress System in the Human Brain in Depression and Neurodegeneration. Ageing Research Reviews, 4, 141-194. https://doi.org/10.1016/j.arr.2005.03.003

[187] Nair, A. and Bonneau, R.H. (2006) Stress-Induced Elevation of Glucocorticoids Increases Microglia Proliferation through NMDA Receptor Activation. Journal of Neuroimmunology, 171, 72-85. https://doi.org/10.1016/j.jneuroim.2005.09.012

[188] Frank, M.G., Thompson, B.M., Watkins, L.R. and Maler, S.F. (2012) Glucocorticoids Mediate Stress-Induced Priming of Microglial Pro-Inflammatory Responses. Brain, Behavior, and Immunity, 26, 337-345. https://doi.org/10.1016/j.bbi.2011.10.005

[189] Biessels, G.J., Staekenborg, S., Brunner, E., Brayne, C. and Scheltens, P. (2006) Risk of Dementia in Diabetes Mellitus: A Systematic Review. The Lancet Neurology, 5, 64-74. https://doi.org/10.1016/S1474-4422(05)70284-2

[190] Ott, A., Stolk, R.P., Hofman, A., van Harskamp, F., Grobbee, D.E. and Breteler, M.M. (1996) Association of Diabetes Mellitus and Dementia: The Rotterdam Study. Diabetologia, 39, 1392-1397. https://doi.org/10.1007/s001250050588

[191] Ott, A., Stolk, R.P., van Harskamp, F., Pols, H.A., Hofman, A., Breteler, M.M., et al. (1999) Diabetes Mellitus and the Risk of Dementia: The Rotterdam Study. Neurology, 53, 1937-1942. https://doi.org/10.1212/WNL.53.9.1937

[192] Janson, J., Laedke, T., Parisi, J.E., O’Brien, P., Petersen, R.C. and Butler, P.C. (2004) Increase Risk of Type 2 Diabetes in Alzheimer Disease. Diabetes, 53, 474-481. https://doi.org/10.2337/diabetes.53.2.474

[193] Hüll, M., Strauss, S., Berger, M., Volk, N. and Bauer, J. (1996) Inflammatory Mechanisms in Alzheimer's Disease. European Archives of Psychiatry and Clinical Neuroscience, 246, 124-128. https://doi.org/10.1007/BF02189112

[194] Aisen, P.S. (1997) Inflammation and Alzheimer's Disease: Mechanisms and Therapeutic Strategies. Gerontology, 43, 143-149. https://doi.org/10.1159/000213842

[195] Neuroinflammation Working Group, Akiyama, H., Barger, S., Barnum, S., et al. (2000) Inflammation and Alzheimer's Disease. Neurobiology of Aging, 21, 383-421. https://doi.org/10.1016/S0197-4580(00)00124-X

[196] Tuppo, E.E. and Arias, H.R. (2005) The Role of Inflammation in Alzheimer's Disease. The International Journal of Biochemistry \& Cell Biology, 37, 289-305. https://doi.org/10.1016/j.biocel.2004.07.009

[197] Swardfager, W., Lanctöt, K., Rothenburg, L., Wong, A., Cappell, J. and Hermann, N. (2010) A Meta-Analysis of Cytokines in Alzheimer's Disease. Biological Psychiatry, 68, 930-941. https://doi.org/10.1016/j.biopsych.2010.06.012

[198] Stauss, D.S., Bauer, J., Ganter, U., Jonas, U., Jpnas, U., Berger, M. and Volk, B. (1992) Detection of Interleukin-6 and Alpha 2-Macroglobulin Immunoreactivity in Cortex and Hippocampus of Alzheimer's Disease Patients. Laboratory Investigation, 66, 223-230.

[199] Altstiel, L.D. and Sperber, K. (1991) Cytokines in Alzheimer's Disease. Progress in Neuro-Psychopharmacology \& Biological Psychiatry, 15, 481-495.

https://doi.org/10.1016/0278-5846(91)90023-T 
[200] Del Bo, R., Angeretti, N., Lucca, E., De Simoni, M.G. and Forloni, G. (1995) Reciprocal Control of Inflammatory Cytokines, IL-1 and IL-6, and Beta-Amyloid Production in Cultures. Neuroscience Letters, 188, 70-74. https://doi.org/10.1016/0304-3940(95)11384-9

[201] Blum-Degena, D., Müller, T., Kuhn, W., Gerlach, M., Przuntek, H. and Riederer, P. (1995) Interleukin- $1 \beta$ and Interleukin-6 Are Elevated in the Cerebrospinal Fluid of Alzheimer's and de novo Parkinson's Disease Patients. Neuroscience Letters, 202, 17-20. https://doi.org/10.1016/0304-3940(95)12192-7

[202] Yamaguchi, H., Hirai, S., Morimatsu, M., Shoji, M. and Ihara, Y. (1988) A Variety of Cerebral Amyloid Deposits in the Brains of the Alzheimer-Type Dementia Demonstrated by $\beta$ Protein Immunostaining. Acta Neuropathologica, 76, 541-549. https://doi.org/10.1007/BF00689591

[203] Tagliavini, F., Giaccone, G., Frangione, B. and Bugiani, O. (1988) Preamyloid Deposits in the Cerebral Cortex of Patients with Alzheimer's Disease and Nondemented Individuals. Neuroscience Letters, 93, 191-196. https://doi.org/10.1016/0304-3940(88)90080-8

[204] Hull, M., Strauss, S., Volk, B., Berger, M. and Bauer, J. (1995) Interleukin-6 Is Present in Early Stages of Plaque Formation and Is Restricted to the Brain of Alzheimer's Disease Patients. Acta Neuropathologica, 89, 544-551. https://doi.org/10.1007/BF00571510

[205] Griffin, M., Strauss, S., Volk, B., Berger, M. and Bauer, J. (1995) Interleukin-1 Expression in Different Plaque Types in Alzheimer's Disease: Significance in Plaque Evolution. Journal of Neuropathology \& Experimental Neurology, 54, 276-281. https://doi.org/10.1097/00005072-199503000-00014

[206] Griffin, W.S. and Mrak, R.E. (2002) Interleukin-1 in the Genesis and Progression of and Risk for Development of Neuronal Degeneration in Alzheimer's Disease. Journal of Leukocyte Biology, 72, 233-238.

[207] Nathan, C. (2002) Points of Control in Inflammation. Nature, 420, 846-852. https://doi.org/10.1038/nature01320

[208] Hanisch, U.K. and Kettenmann, H. (2007) Microglia: Active Sensor and Versatile Effector Cells in the Normal and Pathologic Brain. Nature Neuroscience, 10, 1387-1394. https://doi.org/10.1038/nn1997

[209] Ryu, K.Y., Cho, G.S., Piao, H.Z. and Kim, W.-K. (2012) Role of TGF- $\beta$ in Survival of Phagocytizing: Autocrine Suppression of TNF- $\alpha$ Production and Oxidative Stress. Experimental Neurobiology, 21, 151-157. https://doi.org/10.5607/en.2012.21.4.151

[210] Doyle, K.P., Cekanaviciute, E., Mamer, L.E. and Buckwalter, M.S. (2010) TGF $\beta$ Signaling in the Brain Increases with Aging and Signals to Astrocytes and Innate Immune Cells in the Weeks after Stroke. Journal of Neuroinflammation, 7, 62. https://doi.org/10.1186/1742-2094-7-62

[211] Woods, S.C., Porte, D. Jr., Bobbioni, E., Ionescu, E., Sauter, J.F., Rohner-Jeanrenaud, E. and Jeanrenaud, B. (1985) Insulin: Its Relationship to the Central Nervous System and to the Control of Food Intake and Body Weight. The American Journal of Clinical Nutrition, 42, 1063-1071. https://doi.org/10.1093/ajcn/42.5.1063

[212] Marks, J.L., Porte, D. Jr., Stahl, W.L. and Baskin, D.G. (1990) Localization of Insulin Receptor mRNA in Rat Brain by in Situ Hybridization. Endocrinology, 127, 3234-3236. https://doi.org/10.1210/endo-127-6-3234

[213] Zhao, W., Chen, H., Xu, H., Moore, E., Meiri, N., Quon, M.J. and Alkon, D.L. (1999) Brain Insulin Receptors and Spatial Memory. Correlated Changes in Gene Expression, Tyrosine Phosphorylation, and Signaling Molecules in the Hippocam- 
pus of Water Maze Trained Rats. The Journal of Biological Chemistry, 274, 34893-34902. https://doi.org/10.1074/jbc.274.49.34893

[214] Woods, S.C., Seeley, R.J., Baskin, D.G. and Schwartz, M.W. (2003) Insulin and the Blood-Brain Barrier. Current Pharmaceutical Design, 9, 795-800. https://doi.org/10.2174/1381612033455323

[215] Plum, L., Schubert, M. and Brüning, J.C. (2005) The Role of Insulin Receptor Signaling in the Brain. Trends in Endocrinology and Metabolism, 16, 59-65. https://doi.org/10.1016/j.tem.2005.01.008

[216] Lee, S.H., Zabolotny, J.M., Huang, H., Lee, H. and Kim, Y.-B. (2016) Insulin in the Nervous System and the Mind: Functions in Metabolism, Memory, and Mood. Molecular Metabolism, 5, 589-601. https://doi.org/10.1016/j.molmet.2016.06.011

[217] Kuusisto, J., Koivisto, K., MyKKänem, L., Helkala, E.L., Vanhanen, M., Hänninen, T., Kervinen, K., Kesäniemi, Y.A., Riekkinen, P.J. and Laakso, M. (1997) Association between Features of Insulin Resistance Syndrome and Alzheimer's Disease Independently of Apolipoprotein E4 Phenotype: Cross Sectional Population Based Study. BMJ, 315, 1045-1049. https://doi.org/10.1136/bmj.315.7115.1045

[218] Watson, G.S. and Craft, S. (2003) The Role Insulin Resistance in the Pathogenesis of Alzheimer's Disease: Implications for Treatment. CNS Drugs, 17, 27-45. https://doi.org/10.2165/00023210-200317010-00003

[219] Schubert, M., Gautam, D., Surjo, D., Ueki, K., Baudler, S., Schubert, D., Kondo, T., et al. (2004) Role for Neuronal Insulin Resistance in Neurodegenerative Diseases. Proceedings of the National Academy of Sciences of the United States of America, 101, 3100-3105. https://doi.org/10.1073/pnas.0308724101

[220] Craft, S. (2005) Insulin Resistance Syndrome and Alzheimer's Disease: Age- and Obesity-Related Effects on Memory, Amyloid, and Inflammation. Neurobiology of Aging, 26, 65-69. https://doi.org/10.1016/j.neurobiolaging.2005.08.021

[221] Neumann, K.F., Rojo, L., Navarrete, L.P., Farias, G., Reyes, P. and Maccioni, R.B. (2008) Insulin Resistance and Alzheimer's Disease: Molecular Link \& Clinical Implications. Current Alzheimer Research, 5, 438-447. https://doi.org/10.2174/156720508785908919

[222] De la Monte, S.M. (2009) Insulin Resistance and Alzheimer's Disease. BMB Reports, 42, 475-481. https://doi.org/10.5483/BMBRep.2009.42.8.475

[223] Sjöstrand, M. and Eriksson, J.W. (2009) Neurocrine Mechanisms in Insulin Resistance. Molecular and Cellular Endocrinology, 297, 104-111. https://doi.org/10.1016/j.mce.2008.05.010

[224] Mullins, R.J., Diehl, T.C., Chia, C.W. and Kapogiannis, D. (2017) Insulin Resistance as a Link between Amyloid-Beta and Tau Pathologies in Alzheimer's Disease. Frontiers in Aging Neuroscience, 9, 118. https://doi.org/10.3389/fnagi.2017.00118

[225] Arnold, S.E., Arvanitakis, Z., Macauley-Rambach, S.L., Koenig, A.M., Wang, H.-Y., Ahima, R.S., Craff, S., et al. (2018) Brain Insulin Resistance in Type 2 Diabetes and Alzheimer Disease: Concepts and Conundrums. Nature Reviews Neurology, 14, 168-181. https://doi.org/10.1038/nrneurol.2017.185

[226] Anand, R., Gill, K.D. and Mahdi, A.A. (2014) Therapeutic of Alzheimer's Disease: Past, Present and Future. Neuropharmacology, 76, 27-50. https://doi.org/10.1016/j.neuropharm.2013.07.004

[227] Sutton, R., Keohane, M.E., VanderBerg, S.R. and Gonias, S.L. (1994) Plasminogen Activator Inhibitor-1 in the Cerebrospinal Fluid as an Index of Neurological Disease. Blood Coagulation \& Fibrinolysis, 5, 167-171. 
https://doi.org/10.1097/00001721-199404000-00002

[228] Oh, J., Lee, H.J., Song, J.H., Park, S.I. and Kim, H. (2014) Plasminogen Activator Inhibitor-1 as an Early Potential Diagnostic Marker for Alzheimer's Disease. Experimental Gerontology, 60, 87-91. https://doi.org/10.1016/j.exger.2014.10.004

[229] Albo, D.R., Arnoletti, J.P., Castiglioni, A., Granick, M.S., Solomon, M.P., Rothman, V.L. and Tuszynski, G.P. (1994) Thrombospondin (TSP) and Transforming Factor Beta 1 (TGF-beta) Promote Human A549 Lung Carcinoma Cell Plasminogen Activator Inhibitor Type 1 (PAI-1) Production and Stimulate Tumor Cell Attachment in Vitro. Biochemical and Biophysical Research Communications, 203, 857-865. https://doi.org/10.1006/bbrc.1994.2262

[230] Dennier, S., Itoh, S., Vivien, D., ten Dijke, P., Huet, S., Gauthier, J.M., et al. (1998) Direct Binding of Smad3 and Smad4 to Critical TGF Beta-Inducible Elements in the Promoter of Human Plasminogen Activator Inhibitor-Type 1 Gene. The EMBO Journal, 17, 3091-3100. https://doi.org/10.1093/emboj/17.11.3091

[231] Samarakoon, R., Higgins, C.E., Higgins, S.P., Kutz, S.M. and Higgins, P.J. (2005) Plasminogen Activator Inhibitor Type 1 Gene Expression and Induced Migration in TGF-Beta 1-Stimulated Smooth Muscle Cells Is pp60(c-src)/ MEK-Dependent. Journal of Cellular Physiology, 204, 236-246. https://doi.org/10.1002/jcp.20279

[232] Vivien, D. and Buisson, A. (2000) Serine Protease Inhibitors: Novel Therapeutic Targets for Stroke. Journal of Cerebral Blood Flow \& Metabolism, 20, 755-764. https://doi.org/10.1097/00004647-200005000-00001

[233] Hardy, J. and Selkoe, D.J. (2002) The Amyloid Hypothesis of Alzheime's Disease: Progress and Problems on the Road to Therapeutics. Science, 297, 353-356. https://doi.org/10.1126/science.1072994

[234] Higgins, P.J. (2006) The TGF- $\beta 1 /$ Upstream Stimulatory Factor-Regulated PAI-1 Gene: Potential Involvement and a Therapeutic Target in Alzheimer's Disease. Journal of Biomedicine and Biotechnology, 2006, Article ID: 15792. https://doi.org/10.1155/JBB/2006/15792

[235] Cesari, M., Pahor, M. and Incalzi, R.A. (2010) Plasminogen Activator Inhibitor-1 (PAI-1): A Key Factor Linking Fibrinolysis and Age-Related Subclinical and Clinical Conditions. Cardiovascular Therapeutics, 28, e72-e91.

https://doi.org/10.1111/j.1755-5922.2010.00171.x

[236] Akhhter, H., Katre, A., Li, L., Liu, X. and Liu, R.M. (2011) Therapeutic Potential and Anti-Amyloidosis Mechanisms of Tert-Butylhydroquinone for Alzheimer's Disease. Journal of Alzheimer's Disease, 26, 767-778. https://doi.org/10.3233/JAD-2011-110512

[237] Tjämlund-Wolf, A., Brogren, H., Lo, E.H. and Wang, X. (2012) Plasminogen Activator Inhibitor-1 and Thrombotic Cerebrovascular Diseases. Stroke, 43, 2833-2839. https://doi.org/10.1161/STROKEAHA.111.622217

[238] Kutz, S.M., Higgins, C.E. and Higgins, P.J. (2012) Novel Combinatorial Therapeutic Targeting of PAI-1 (SERPINE1) Gene Expression in Alzheimer's Disease. Molecular Medicine, 1, 106-110. https://doi.org/10.4172/2324-8769.1000106

[239] Aprahamian, I., Stella, F. and Forlenza, O. (2013) New Treatment Strategies for Alzheimer's Disease: Is There a Hope? Indian Journal of Medical Research, 138, 449-460.

[240] Yildiz, S.Y., Kuru, P., Oner, E.T. and Agirbasli, M. (2014) Functional Stability of Plasminogen Activator Inhibitor-1. The Scientific World Journal, 2014, Article ID: 858293. https://doi.org/10.1155/2014/858293 
[241] Mannarino, E., Pasqualini, L., Ciuffetti, G. and Lombardini, R. (1992) Effect of Oral Administration of Sulodexide on Fibrinolysis and Plasma Viscosity: A Pilot Study. Drug Investigation, 4, 346-350. https://doi.org/10.1007/BF03259415

[242] Cocchery, S. and Mannello, F. (2014) Development and Use of Sulodexide in Vascular Diseases: Implications for Treatment. Drug Design, Development and Therapy, 8, 49-65. https://doi.org/10.2147/DDDT.S6762

[243] Baluta, M.M. and Vintila, M.M. (2015) PAI-1 Inhibition-Another Therapeutic Option for Cardiovascular Protection. Maedica, 10, 147-152.

[244] Lasierra Cirujeda, J., Aza Pascual-Salcedo, M.J. and Aza Pascual-Salcedo, M.M. (2016) Sulodexide and Alzheimer's Disease: A Preliminary Prospective Study. World Journal of Cardiovascular Disease, 6, 54-71. https://doi.org/10.4236/wjcd.2016.62007

[245] Lasierra-Cirujeda, J., Coronel, P., Aza Pascual-Salcedo, M.J., Gimeno, M., Aza Pascual-Salcedo, M.M., Lasierra-Ibañez, A. and Lasala-Aza, C. (2018) Stress/Inflammation and PAI-1 as Stellar Processes in the Aging and Associated Pathologies. Integrative Molecular Medicine, 5, 1-2. 